\title{
片脚膝立ち位保持の姿勢制御に関する研究
}

—体重心と圧中心の関係——

\section{Postural Control during Single-leg Kneeling: Relationship of COG with COP}

\author{
川上真吾 ${ }^{1,2)}$ 鈴木 博人 ${ }^{1,2}$ 菊地 明宏 ${ }^{3)}$ 田中 直樹 ${ }^{2)}$ \\ 樋口 朝美 ${ }^{1)}$ 西山 徹 ${ }^{4)}$ 藤澤 宏幸 ${ }^{1,2}$
}

SHINGO KAWAKAMI, MS ${ }^{1,2)}$, HIROTO SUZUKI, MS ${ }^{1,2)}$, AKIHIRO KIKUCHI, MS ${ }^{3)}$, NAOKI TANAKA, MS ${ }^{2)}$, AsAmI HIGUCHI, RPT ${ }^{1)}$, TORU NISHIYAMA, RPT, RhD ${ }^{4)}$, HIROYUKI FUJISAWA, PRT, RhD ${ }^{1,2)}$

${ }^{1)}$ Graduate School of Health and Environment Science, Tohoku Bunka Gakuen University: 6-45-1 Kunimi, Aoba-ku, Sendai-shi, Miyagi 981-8551, Japan.TEL+81 22-207-3730 E-mail: kawakami@rehab.tbgu.ac.jp

2) Department of Rehabilitation, Faculty of Medical Science \& Welfare, Tohoku Bunka Gakuen University

${ }^{3)}$ Department of Rehabilitation, Miyagi Eastern Cardiology

${ }^{4)}$ Department of Rehabilitation of Installation Preparation Room, Japan Health Care, University

Rigakuryoho Kagaku 30(3): 399-403, 2015. Submitted Dec. 8, 2014. Accepted Jan. 18, 2015.

ABSTRACT: [Purpose] This study was conducted to clarify postural control during single-leg kneeling. [Subjects] The subjects were 28 healthy adults. [Methods] The mean power frequency of the center of pressure was calculated for all subjects. Subjects were divided into possible and not possible groups on the basis of being able to hold a single-leg kneeling position for more or less than $30 \mathrm{~s}$, and the groups' mean power frequencies were calculated for the center of gravity and center of pressure and compared. [Results] The mean power frequency of the center of pressure was about $2.1 \mathrm{~Hz}$. The mean power frequency of the center of gravity showed a tendency to be higher in the possible group. [Conclusion] Control of the center of pressure was found to be important during single-leg kneeling. Key words: single-leg kneeling, COG, COP

要旨:〔目的〕片脚膝立ち位保持における姿勢調整戦略を明らかにすることである。〔対象〕健常成人 28 名とした。〔方 法了全対象者における圧中心の平均パワー周波数を算出した。次に片脚膝立ち位保持が 30 秒可能群（以下，可能 群), 30 秒未満群（以下, 不可群）に割り付け, 体重心および圧中心の平均パワー周波数を算出し, 比較した。〔結果〕 圧中心の平均パワー周波数 $2.1 \mathrm{~Hz}$ であった. 体重心の平均パワー周波数において, 可能群で高い傾向が認められた. 30 秒保持可能な対象者と明らかに保持困難である対象者では各指標の平均パワー周波数で明らかな差が観察された. 〔結語〕圧中心の制御に着目することが重要であると示唆された.

キーワード：片脚膝立ち位保持, 体重心, 圧中心

1) 東北文化学園大学大学院 健康社会システム研究科:宮城県仙台市青葉区国見6丁目 45-1 ( 9 981-8551) TEL 022-207-3730

2) 東北文化学園大学 リハビリテーション学科

3) みやぎ東部循環器科リハビリテーション科

4) 日本医療大学 リハビリテーション学科 設置準備室

受付日 2014 年 12 月 8 日 受理日 2015 年 1 月 18 日 


\section{I. はじめに}

膝立ち位は日常の様々な場面で要求され 1), 文化や職 業, 理学療法における治療との関連が強い. 特に中東や アジア諸国では，文化と膝立ち位との結びつきが強いの が特徵である。これは, 宗教活動に代表される祈りの姿 勢において必要不可欠な能力 ${ }^{2-4)}$ とされているからであ る. 一方, 日本の生活様式は坐を中心としたもの5)で あることはいうまでもない，床を拭く動作などの目的を 達成するための姿勢であると同時に，正座から立位にな る際の移行姿勢でもある。つまり，日本文化にとって膝 立ち位は切り離すことのできない姿勢といえる。また， 職業分野では, 整備業, 造園業, 建設業, 配管業, 炭鉱 業と関連があるとされている。これらの職業では，日常 的に膝立ち位を反復している点で共通している.

理学療法分野では, 膝立ち位を評価や治療の 1 つとし て用いることが多い，なぜなら，膝立ち位は，足関節に よるバランス制御を利用できず，股関節による姿勢制御 が中心とならざるを得ない6)ことから，股関節制御に 焦点をあてた評価および, 治療が可能であると理解され ているからである。しかしながら，これまでに運動学・ 運動力学的な検討が十分になされてきたとはいい難い. 特に, 難易度の高いバランス課題として知られる膝立ち 位から片脚を挙上し, 姿勢を保持する片脚膝立ち位保持 のデータについては, 我々の知る限り見当たらない。 そ れゆえ, 根拠に基づいた検査・治療の組み立てがなされ ていないのが現状である。よって, 片脚膝立ち位保持の 運動学および運動力学的な説明ができれば, 評価や治療 の意義を考える上で重要な示唆を与えてくれると考え る.

これまで, 片脚膝立ち位保持における研究を実施して きた7)．片脚膝立ち位保持におけるバランス制御につい ては, 一般的には前額面における股関節運動によって体 重心（以下, center of gravity：COG）を制御している と考えられてきたことから股関節外転筋との関係につい て検証した。 その結果, 片脚膝立ち位保持課題において 基本的には股関節外転筋によって COG 制御が行われて いると示唆された。しかしながら，その説明率 ${ }^{8)}$ は約 $30 \%$ と低いことから, 異なる機能が関与している可能 性も考えられた。

実験上における観察では，長時間保持が可能な被験 者の特徴として下腿の回旋が観察された。身体が平衡を 保つためには, COG の作用線と圧中心（以下, center of pressure : COP) の位置関係が一致しているほど安定 性が高いことなる。特に, 静止課題においては, COP の制御により COG を一定位置に留める戦略が基本とな る.つまり, 片脚膝立ち位保持のような静止課題では, 股関節による COG の制御のみならず, COP の制御も作 用している可能性があった. 以上の論点から, 仮説とし
て以下のことが考えられた．片脚膝立ち位保持のような 静止課題においては，(1)COPの制御が関与している. さらに，(2)保持可能である場合，狭小化した支持基底面 内に重心を留めるためには，より素早くCOP を制御す る必要があると予測されることから COP の制御が困難 である場合に比し，有意に高い周波数成分を示す.

よって, 本研究の目的は, 片脚膝立ち位保持での COPの制御による姿勢調整の有無を明らかにすること である。ささらに, 保持可能群と不可群との 2 群間におい て, $\mathrm{COG}$ の平均パワー周波数 (以下, mean power frequency : MPF), COPの MPF, COG および COP 両 者の MPF の分散を比較し保持を可能にする要因を明ら かにすることとした。

\section{II. 対象と方法}

1. 対象

健常成人 28 名（年齢 $21.6 \pm 3.1$ 歳, 身長 $168.9 \pm 8.6$ $\mathrm{cm}$, 体重 $62.1 \pm 10.6 \mathrm{~kg}$ ) とした。軸足については, 「ボールを蹴る足」の反対側として定義し, 全員が左脚 であった。なお，片脚膝立ち位を制限する中枢疾患，整 形外科疾患, 視覚障害や前庭障害等のバランス機能に影 響を及ぼす障害とその既往が無いことを事前に確認し た，対象者には研究内容を十分に説明したのち，署名を 持って承諾を得た。本研究は東北文化学園大学研究倫理 委員会にて承諾を受け実施した（承認番号；文大倫第 13-07 号).

\section{2. 方法}

測定環境に関して, 床反力計（MG-1090, ANIMA） 2 枚上で片脚膝立ち位保持課題を実施する際の膝関節位 置から $3 \mathrm{~m}$ 前方にターゲットを設置した。加えて, 課 題遂行状況における三次元座標の計測を可能とするため, 三次元動作カメラ（ローカス 3D MA-5000,

ANIMA）は 6 台とした。

開眼片脚膝立ち位保持を計測し, その後, 保持時間で 2 群に割り付けた。開眼片脚膝立ち位保持可能群（以下 可能群) の条件については，30 秒保持が可能であると 定義した。一方, 片脚膝立ち位保持不可群（以下，不可 群) の条件については, 保持時間が 30 秒未満であると 定義した。この保持時間 30 秒を境界とした理由につい ては, 以下の 2 点が挙げられる. 1 つ目は, 先行研究に おいて，30 秒保持が可能な被験者では, 明らかな下腿 の回旋が確認できた．2つ目は，片脚立位保持などバラ ンス検査に拈いて，30 秒をバランス能力の判断基準に している9）検査もある. 課題については, 開眼片脚膝 立ち位保持とした。開始肢位は，床反力計上に膝立ち位 にて前胸部で腕を組み, 股関節中間位, 膝関節 $90^{\circ}$ 屈曲 位，足関節底屈位となる構えとした。片脚膝立ち位保持 
は, $3 \mathrm{~m}$ 先のターゲットを注視し, 支持脚の股関節は可 能な限り屈曲伸展中間位を保持する方法で統一した。測 定開始は, 音合図の後, 非軸足を挙上しその肢位が床か ら離れ圧中心が一つとなった時点とした。課題遂行にあ

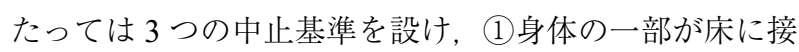
地した場合，(2)前胸部での腕組みが外れた場合，(3)保持 時間が 30 秒に達した場合とした。

測定条件は, 開眼片脚膝立ち位保持の 1 条件とした. 施行は計 2 回とし, 各施行による疲労の影響を排除する ため，施行間に十分な休憩を設けた。制御については, 特別な指示は与えなかった。課題の実施にあたり，事前 に何度か練習を行った。

データ集積には，三次元動作解析装置を用いた。 反射 マーカーを貼付する骨指標は, 頭頂, C7 棘突起, 両側 肩峰, 両側上前腸骨棘, 両側大転子, 両側外側裂隙, 軸 脚内側裂隙, 両側外果, 軸脚内果の計 14 箇所として設 定した。 反射マーカーの位置をサンプリング周波数 150 $\mathrm{Hz}$ で計測した。同時に, 床反力計 2 枚を用いて左右下 肢それぞれの床反力と圧中心データをサンプリング周波 数 $150 \mathrm{~Hz}$ で計測した。本研究では, 位置座標について は前額面の位置座標データを, 床反力データについては 鉛直方向成分と左右成分を用いた。体重心位置の計算に ついては，矢状面および前額面に頭部・体幹・上肢 (head, arms, and trunk; HAT), 両大腿, 両下腿, 両足部 からなる 7 つ剛体リンクモデルを仮定し, 平滑化され た座標データと Winter ${ }^{10)}$ の人体座標デー夕を用いて $\mathrm{COG}$ の座標を求めた. COP については, 床反力の垂直 分力の值から, 平面座標を算出した. その後, COG お よび, $\operatorname{COP} の$ 座標変化のデータの内 $571 \sim 1,595$ 個目 (210 個のデータ) の安定したデータを切り出し高速フー リエ変換 (FFT) にて平均パワー周波数 (mean power frequency: MPF) を算出した，分散については，COGお よび, COPにおける MPFの標準偏差を用いて算出した。 デー夕解析に関して, COPにおける MPFの平均值お よび標準偏差, 中央值を算出した。2 群間における各指
標（COG の MPF, COP の MPF）の差の比較には, Mann-Whiteny U 検定を用いた，2群間における COG の MPF およびCOPの MPFにおける分散の比較には， Lepage testを用いた。加えて, 保維持不可群の内, 明 らかに保持が困難であった被験者と保持可能群で各項目 について比較を行った。ただし，明らかに保持が困難で あった被験者は数例のみであったため統計学的処理は実 施していない.

統計学的有意水準は危険率 5\%とし，10\%未満は有意 差傾向があるとした。各々のデータは平均值と標準偏差 および中央值で示した。解析はEZR ver,1.8-1.を用いた。

\section{III. 結 果}

片脚膝立ち位保持における COP の平均周波数成分は $2.1 \pm 0.3 \mathrm{~Hz}$ ，中央值は $2.1 \mathrm{~Hz}$ であった。全被験者にお いて COP の周波数成分が確認され，COP が律動的に動 いていることが認められた。次いで，片脚膝立ち位保持 時間で 2 群（可能群・不可群）に群分けを行った結果, 可能群は 15 名, 不可群は 13 名であった. 不可群の保 持時間別割合については, 保持時間 $1 \sim 6$ 秒未満が 2 名, $6 \sim 11$ 秒未満が 1 名, $11 \sim 21$ 秒未満が 5 名, $21 \sim 30$ 秒未満が 5 名となり保持時間に差のある集団となった。 2 群それぞれの COG および, COPの MPF, COGの MPF およびCOPのMPFにおける分散について, 平均 值と標準偏差, 中央值を表 1 に示す. 片脚膝立ち位保持 における周波数帯域, おおよそ COG は $0.6 \mathrm{~Hz}$ の周波数 帯, COPは2.1 Hzの周波数帯であった. COPにおいて は, COGに比し周波数帯域が高い傾向を示した。各項 目について，2 群間における差の比較を行ったが有意差 は認められなかった。ただし，COGのMPFにおいて は可能群が不可群に比し周波数帯域が高い傾向を示し た.この傾向については, 図 1 に示した散布図からも伺 うことができた。明らかに保持困難であるとした保持時 間 5 秒の各データについては, COG の MPF は $0.2 \mathrm{~Hz}$,

表 12 群間での COG の MPF, COP の MPF, COG およびCOP の MPF 分散の比較

\begin{tabular}{|c|c|c|c|c|}
\hline & & 不可群 $(n=13)$ & 可能群 $(\mathrm{n}=15)$ & \\
\hline $\begin{array}{l}\mathrm{COG} \\
\text { (中央値) }\end{array}$ & $(\mathrm{Hz})$ & $\begin{array}{c}0.4 \pm 0.2 \\
0.3\end{array}$ & $\begin{array}{c}0.5 \pm 0.3 \\
0.6\end{array}$ & $*$ \\
\hline $\begin{array}{l}\text { 分散 } \\
\text { (中央值) }\end{array}$ & $(\mathrm{cm})$ & $\begin{array}{c}0.1 \pm 0.1 \\
0.1\end{array}$ & $\begin{array}{c}0.1 \pm 0.1 \\
0.1\end{array}$ & \\
\hline $\begin{array}{l}\mathrm{COP} \\
\text { (中央値) }\end{array}$ & $(\mathrm{Hz})$ & $\begin{array}{c}2.1 \pm 0.3 \\
2.0\end{array}$ & $\begin{array}{c}2.1 \pm 0.3 \\
2.1\end{array}$ & \\
\hline $\begin{array}{l}\text { 分散 } \\
\text { (中央值) }\end{array}$ & $(\mathrm{cm})$ & $\begin{array}{c}0.1 \pm 0.1 \\
0.1\end{array}$ & $\begin{array}{c}0.1 \pm 0.1 \\
0.1\end{array}$ & \\
\hline
\end{tabular}

$* 0.05 \leq \mathrm{p}<0.10$. 

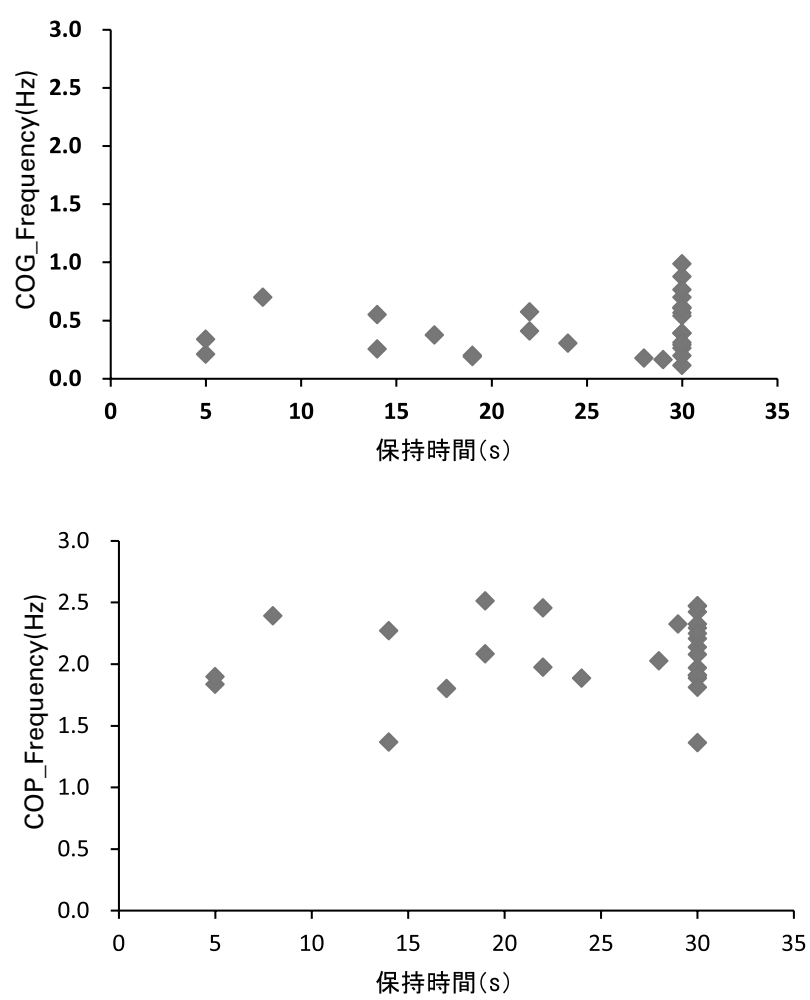

図1保持時間とCOGおよびCOPのMPFによる散布図 左：保持時間と COGのMPFによる散布図 右：保持時 間とCOPのMPFによる散布図

COP の MPF は $1.8 \mathrm{~Hz}$ の周波数帯域であり, 可能群で 示された $\mathrm{COG} の \mathrm{MPF}$ は $0.5 \mathrm{~Hz}, \mathrm{COP} の \mathrm{MPF} 2.1 \mathrm{~Hz}$ に比し低い周波数であった。

\section{IV. 考 察}

先行研究の結果より, 片脚膝立ち位保持においては, 基本的には股関節外転筋による COG 制御が関与してい ることが示唆された，さらに，実験上における観察では， 一定時間保持が可能な被験者の特徽として下腿の回旋が 観察された。つまり，片脚立位保持における足部の内返 し・外返しによる制御 11-14) と同様に，片脚膝立ち位保 持においても COPの制御がその保持に関与している可 能性があった。そこで，我々は，上記を明らかにするた めに以下の $2 つ の$ 仮説について検証を行った。 (1)片脚膝 立ち位保持のような静止課題においては, COPの制御 が関与している.さらに, (2)保持可能である場合, COP の制御が困難である場合に比し，有意に高い周波数成分 を示す

COPにおけるMPFの結果より, 全被験者において 2.1 $\pm 0.3 \mathrm{~Hz}$ の変動が認められ, 片脚膝立ち位保持におい て COP の制御が関与していることが示唆された。一方, 片脚膝立ち位保持課題における保持要因の検証において は, 被験者を可能群と不可群の 2 群間に割り付け, MPF
および分散について，差の比較を行った。その結果，有 意差は認められなかった。本研究では，不可群の保持時 間を 30 秒未満と設定したことから 5 〜 29 秒までの幅 がある集団となった。よって，ほぼ全対象者において一 定時間は片脚膝立ち位保持が可能であったことになる。 COG と COP が相互作用を示した時期，すなわち 571〜 1,595 番目のデータを切り出し代表值を算出したことか ら，有意差は認められなかったと考えている。しかしな がら, COGのMPFは不可群に比し可能群で高い傾向 を示した。この結果は, 先行研究の股関節外転筋による COG 制御が関与しているとした見解と関連している. つまり, 片脚膝立ち位保持には, 前提条件として一定水 準に達した MPFによる COGの制御が必要である。こ の制御に股関節外転筋が寄与している可能性があるとい うことになる。

次に，個々で次データを比較した。 方法に示した通り， 明らかに保持が困難であると判断した保持時間 5 秒の対 象者と，30 秒保持が可能であった対象者を比較したも のである，比較対象がシングルケースであるため，統計 学的処理を行っていない. COG およびCOP の MPFの 比較では, 明らかに保持が困難であった対象者の值に比 し高い傾向を示し, 差が生じていることが確認できた. 以上を踏まえると, 片脚膝立ち位保持を可能とする条件 の 1 つとして, おおよそ $\mathrm{COG}$ は $0.6 \mathrm{~Hz}$ の周波数帯, COP は $2.1 \mathrm{~Hz}$ の周波数帯での調整能力を持ち合わせて いることが重要であると思われる。この, COPの制御 による $2.1 \mathrm{~Hz}$ は，片脚立位保持において側方安定性に 寄与する足部の内返し ・ 外返し運動の周波数 $2 \mathrm{~Hz}$ 以 上 3)であるとする報告と類似している。また，それぞ れの支持基底面の形状においても，前後方向に比し，左 右方向が非常に狭いという点で共通性を認める。よって, 片脚膝立ち位保持における COP 制御は, 片脚立位保持 における足部の内返し・外返しと同様の役割を果たして いると考えられる。ただ，片脚膝立ち位保持における COP制御については，下腿の回旋によりそれを実現し ていることから， $2.1 \mathrm{~Hz}$ の周波数帯から大きく変動す ることはないと思われる。

ここで，片脚膝立ち位保持を可能にする条件を整理す る。第 1 に，非支持側の骨盤下制を抑止可能な股関節機 能が確保されていることが前提となる．第 2 に, COG 制御により頭部・上肢・体幹（head arm and trunk： HAT）の安定性が担保されている条件下では，COP制 御を基本としてバランスを制御している。第 3 に, $\mathrm{COG}$ と COP の大きなずれに対してすばやく対応可能な $\mathrm{COG}$ 制御によって COG を一定の位置に保持している. つまり, 保持を可能にするための階層構造が存在してい ると推察された。しかしながら，片脚膝立ち位保持が可 能であっても COG の MPF が低い值を示す対象者も存 在していた。本研究では, 片脚膝立ち位保持が可能で 
あっても COG の MPF が低い值を示すことについて明 らかにすることができていないことから，その点につい て慎重に判断する必要がある.

これまで考察してきたように，片脚膝立ち位保持にお いて階層性に注目することで COG 制御および COP 制 御の関係を説明できることは，検査・治療の意義を考え る上で重要な示唆を与えてくれている，関節運動の調節 能を間接的に評価し，それが動作に与える影響を検討で きる可能性を示しているからである。 今後, COP 制御 に注目して運動学および運動力学的な検討を加えること により，検査・治療としての意義をより明確にできるも のと考えている。

\section{引用文献}

1) Jason $\mathrm{K}$, Ryuichi G, Michelle H, et al.: Effects on tibiofemoral biomechanics from kneeling. Clin Biomech, 2011, 26(6): 605-611.

2) Kurosaka M, Yoshiya S, Mizuno K: Maximizing flexion after total knee arthroplasty the need and the pitfalls. J Arthroplasty, 2002, 17(4): 59-62.

3) Moon M, Moon J: Range of motion after total knee replacement: a review from the East. Curr Orthopaed, 2000, 14(4): 302-308.

4) Mulholland S, Wyss U: Activities of daily living in nonWestern cultures: range of motion requirements for hip and knee joint implants. Int J Rehabil Res, 2001, 24(3): 191-198.
5) 藤澤宏幸：姿勢の定義と分類の再考. 理学療法の歩み, 2013, 24(1): 31-34.

6) 倉山太一, 影原彰人, 村越大輝・他 : 膝立ち運動が脳卒中 片麻㾝患者の立位バランスに与える即時的効果. 総合リ八, 2011, 39(8): 791-794.

7) 川上真吾：片脚膝立ち位保持時間と股関節外転筋におけ る筋力発揮特性との関係. 理学療法の歩み, 2014, 25(1): $42-46$.

8) 田中 敏, 山際勇一郎：ユーザーのための教育・心理統計 と実験計画法. 教育出版, 東京, 2011, pp188-189.

9) Bohannon R, Leary K: Standing balance and function over the course of acute rehabilitation. Arch Phys Med Rehabil, 1995, 76(11): 994-996.

10) Winter D: Biomechanics and Moter Control of Human Movement 2nd, John Wiley \& Sons Inc., New Jersey, 1990, pp85-88.

11) King D, Zatsiorsky V: Periods of extreme ankle displacement during one-legged standing stance. Gait Posture, 2002, 15(2): 172-179.

12) Tropp H, Odenrick P: Postural control in single-limb stance. J Orthop Res, 1988, 6(6): 833-839.

13) Hoogviet P, Van W, Johan V, et al.: A model for the relation between the displacement of the ankle ant the center of pressure in the frontal plane, during one-leg stance. Gait Posture, 1997, 6(1): 39-49.

14) Davis B, Grabiner M: Modeling effects of muscle fatigue on unilateral postural control. J Appl Biomech, 1996, 12(2): 173-184. 